\title{
Brief Analysis of Legal Effect on Negotiorum Gestio
}

\author{
Nannan Chen \\ The Oriental Institute of Shandong University of Finance and Economics, Shandong, China
}

Keywords: Negotiorum gestio, Prevention from punishment, Legal effect

\begin{abstract}
The effectiveness of negotiorum gestio refers to the effect and force that can be caused when the behavior is satisfied with the essential elements of the management. It covers the debt obligation relationship between prevention from punishment and the civil subject of negotiorum gestio.
\end{abstract}

\section{Introduction}

As one of the main legal facts about the occurrence of debt, the relevant data shows that the earliest of negotiorum gestio system originated from Roman law, and then went through the development of history for thousands of years. Although this important legal system has experienced the baptism of the past thousand years, which should have been developed, its development is very limited. This article will introduce and research the legal effect on negotiorum gestio.

\section{The real negotiorum gestio}

\subsection{Law effect of comfortable negotiorum gestio}

For the comfortable negotiorum gestio, the effect and force of two aspects can be triggered after meeting the constitutive requirement. Firstly, irregularity. Negotiorum gestio under the proper law is still in the affairs of others. In principle, it should be treated as a tort. However, because the legitimacy and necessity of the negotiorum gestio establishment, the law gives it the irregularity effect as a legal action. Secondly, the relationship of rights and obligations between the manager and himself. The relationship of creditor's rights and liabilities arising out of the negotiorum gestio, the administrator and himself enjoy each other's rights and obligations. The author will analyze the content of the debt from the manager's rights and obligations.

\subsubsection{Obligation of administrator}

Since the law endows negotiorum gestio with prevention from punishment, it becomes a lawful act, we should use the utility to manage other people's affairs and will protect the lawful rights and interests of civil subjects [1]. The duty of a manager has primary and secondary obligations. The appropriate management obligation is a primary obligation, notification and calculation obligations are subordinate obligations [2].

(1) Proper management obligation. Proper management means that the manager is in charge of other people's affairs, protect its interests in a manner that is in accordance with the own express or presumable means. Firstly, the manager shall manage the business in the manner in which he or she may or may infer the meaning of the speculation. Assuming that the manager protects his or her interests in an express manner, then it is not a negotiorum gestio, but a contract. For example, I have made it clear that the lines in my home are old and disrepair, and I need to repair them in case of fire. On a stormy night, I went out. The neighbors came forward to help repair it in order to prevent the fire. I have made clear my intention to maintain the line, which is the express. Therefore, the behavior of the neighbors belongs to negotiorum gestio. But if that I have had the intention of having the maintenance line for my neighbor alone, that would constitute a principal-agent [3]. It can be inferred that the manager can infer the meaning of the person based on his own experience and experience without his own express. In general, the criterion for inferred speculation should be 
based on the own interests. The specific standards should be combined with wishes and needs, the basic knowledge of transaction management, and the knowledge and experience gained by managers in practice [4]. The management of a transaction shall not injure the interests of the manager and incur losses. The administrator shall manage in a manner that is beneficial to himself in order to prevent his own interests from being damaged.

(2) Duty of notification. Notification obligation refers to the responsibility of the administrator to inform himself that the negotiorum gestio management has started and that he is aware of it. After all, the management is caused by the own affairs, which is involved in the own interests. In principle, the person should have the right to know. However, the manager's notification behavior should be carried out if possible or necessary. Firstly, assuming that I already know the beginning of a management transaction, the manager may not perform the notification obligation. Secondly, if the manager does not fulfill the possibility of notification obligation in real life, then the administrator may not perform the notification obligation. Thirdly, as long as the manager's business is not an emergency, it should wait for me to decide whether or not to continue the management before it is notified to me. Assuming that the waiting process will damage my interests, then the manager can wait and manage the transaction immediately.

(3) Reporting management and computing obligations. After the commencement of negotiorum gestio, the manager shall report the management and calculation to himself. In the first place, report the implementation of management to me and let it know the specific process, especially when the behavior ends, more should be put on record to me. Secondly, the administrator shall give the rights and property of the management, including the interest accrued therefrom. Thirdly, whether for the sake of oneself or oneself benefit, as long as the manager spends the money that should be handed over to me, from the day that the cost begins to calculate interest. In addition, the administrator shall be liable for damages if the expenses are harmed in the interests of the person.

\subsubsection{Administrator's rights}

(1) The right to reimburse the necessary expenses. The "necessary expenses" here can be understood as necessary or beneficial and interest accrued from the time spent. All the necessary expenses manager may request repayment. The criteria for measuring whether the costs are necessary shall be determined according to the actual situation. In the case of management behavior, the cost of the general situation is necessary. Even if the later costs are too high, it should be deemed necessary. On the other hand, if it is not necessary to expend the cost, even if it is necessary in the future, it will not be necessary.

(2) Claim for debt repayment. As long as it is necessary or beneficial to the person, the administrator may claim the debt repayment after undertaking the transaction management process.

(3) Claim of compensation for damage. Claim of compensation for damage means the managers in the process of negotiorum gestio is hurt and loss, as long as the causal relationship between damage loss and management affairs, so the administrator shall have the right to request to pay to himself. If the manager is at fault for the loss of injury, it is reasonable to reduce his liability according to the actual situation [6].

(4) Reward request right. Reward request right always been one of the important debates in the academic field and in practice. Mr. Hu Changqing, a scholar in Taiwan, argues that the administrator does not have the right to claim compensation. On the contrary, Mr Zheng Yubo, who is also from Taiwan, argues that managers should be entitled to compensation claims: The negotiorum gestio management system not only protects people's own interests, but also seeks social benefits. Wouldn't it make more sense to give the manager a reward for his reward [6]? In addition, Mr. Wang Zejian also believes that managers should be given the right to ask for compensation, but they must meet certain conditions. For example, the manager is in charge of other people affairs-- salvage at sea. This view is available for reference [2]. The author believes that, according to the principle of fairness, the right of remuneration of the manager can be appropriately affirmed under the following conditions. Firstly, assuming the outcome of the management activities, the benefit that I should have reduced is not reduced, so the manager is not 
entitled to the right of remuneration. Secondly, assuming the results of the management activities, my interests not only have not decreased but increase, so the manager can enjoy a certain amount of compensation claim. In this way, we can make the management behavior more consistent with the requirements of fairness and justice, and also increase the enthusiasm of people to help each other.

\subsection{The legal effect of discomfort negotiorum gestio}

The provisions of the "General Principles of the Civil Law" in our country are relatively simple, and there is no clear stipulation on the legal effect of discomfort negotiorum gestio. In the discussion of the legal effect of the discomfort negotiorum gestio, it mainly referred to the legal provisions and related works in Taiwan. This view is available for reference [2].

\subsubsection{Obligation of administrator}

(1) The tort liability of the administrator. The conduct of other people's affairs is detrimental to the interests of the person or to the behavior that deviates from its explicit or inferential meaning. It becomes illegal to deprive the management of its resistance but violate the law. Therefore, if the administrator infringes upon his right and is intentionally or negligent, he is the subject of a subjective mental attitude, it should be handled according to the tort, the parties bear the liability for compensation.

(2) The aggravation of administrator responsibility. The manager deviates from himself or can infer the meaning of the speculation. As long as the management results infringe on the interests of the person, even if the manager is not negligent, it should be liable for compensation. Of course, in the specific application process, we should also grasp two points: Firstly, the manager shall be liable for compensation as long as the management act deviates from the person's express or inferred and causes the fact to be damaged. Secondly, the manager takes the subjective psychological attitude of intentionally or negligent to conduct the transaction management, and the manager shall be responsible for the risks arising therefrom and assume the responsibility of no fault.

(3) The mitigation of administrator responsibility. When the personal and property safety of the person is in urgent danger, the management of the person to eliminate its danger is the management behavior. In principle, even if the damage is done to the person, he or she shall not be liable for compensation. Unless the manager carries out the act out of good will or gross negligence.

\subsubsection{Personal rights and obligations}

In the discomfort negotiorum gestio, the content of personal rights and obligations will be interpreted differently depending on the circumstances.

The persona claims that he or she enjoy the benefits of negotiorum gestio. In such case, the person shall bear the necessary expenses, pay off the necessary debts and indemnify the administrator at the same time. Of course, the foregoing obligation shall be subject to the maximum benefit that he or she can obtain in the absence of management.

The person does not claim to enjoy the benefits of negotiorum gestio. Since we do not advocate the rights in the management, we do not have to assume corresponding obligations. At this time, the legal relationship between the parties can be dealt with according to unjust enrichment and the rules of tort.

\section{Unreal negotiorum gestio}

\subsection{Unreal negotiorum gestio}

The unreal negotiorum gestio means the act of managing a business without knowing it is someone else's business. For the affairs of others, the actor is a kind possessor, but this kind of behavior cannot be regarded as the negotiorum gestio. Because it does not satisfy its subjective elements. In judicial practice, the author thinks that it should be handled according to the law of tort or unjust enrichment. 


\subsection{Illegal management}

If unreal negotiorum gestio is a benevolent possession of a person's affairs to others, illegal management is a malicious possession of the perpetrator to others. This is the act of managing a business that knows it is someone else's business. This kind of behavior cannot be regarded as the negotiorum gestio, or because it does not satisfy its subjective constitutive elements. In judicial practice, the author thinks that it should be handled according to the law of tort or unjust enrichment. However, according to the tort or unjust enrichment of the law to solve the problem, is also defective, is not able to perfect the preservation of personal interests. For example, there are times when claims of damages for infringement or claims for restitution are not as good as the benefit of the parties. However, if the person claims damages to the manager in accordance with the provisions of the tort, he or she can only claim the damages and the actual reduction of the benefits due to the illegal management. If it is required to return the unjust enrichment, it must be subject to the maximum amount of damage suffered by the person. The law stipulates that the interest is less than the damage, and the benefit is greater than the damage. In other words, the administrator has no right to request the return of the benefits beyond this limit. Moreover, it is difficult to argue for the limitation of the limitation of short - term action. It can be seen that the above method can solve the problem and cannot fully protect the personal interests [3]. We might adopt the "German Civil Code”, and apply the illegal management in the rules of negotiorum gestio, and treat the managers of the illegal management as the real negotiorum gestio managers. In this way the person can claim to the manager that all the benefits have been returned. However, there must be a strict precondition -- to manage the affairs of others as if they were their own. The management of the administrator due to "negligence" shall still be dealt with in the light of the infringing act or the legal provisions of unjust enrichment.

\section{References}

[1] Wang Liming. Case Studies in Chinese Civil Law [M] Beijing: Law Press, 1998: 103-109

[2] Wang Zejian. Civil Law Theory and Case Study (Book II) [M] Beijing: China University of Politic Science and Law Press, 2005: 72-73

[3] Zheng Yubo. General Theory of Civil Law Debt (Amendment 2) [M] Beijing: China University of Politic Science and Law Press, 2004: 77-90

[4] Ma Junju. She Yanman. The Original Theory of Civil Law (Second Edition) [M] Beijing: Law Press, 2005: 779

[5] Wang Jiafu. Chinese Civil Law •Creditor's Rights [M] Beijing: Law Press, 1991: 584

[6] Zheng Yubo. General Theory of Civil Law Debt [M] Beijing: China University of Politic Science and Law Press, v 